\title{
"Kambô" frog (Phyllomedusa bicolor): use in folk medicine and potential health risks
}

\author{
Francisco Vaniclei Araújo da Silva[1],[2], Wuelton Marcelo Monteiro ${ }^{[3],[4]}$ \\ and Paulo Sérgio Bernarde ${ }^{[1],[2]}$
}

\begin{abstract}
[1]. Laboratório de Herpetologia, Centro Multidisciplinar, Campus Floresta, Universidade Federal do Acre, Cruzeiro do Sul, AC, Brasil. [2]. Programa de Pós-Graduação Stricto Sensu em Ciências da Saúde na Amazônia Ocidental, Universidade Federal do Acre, Rio Branco, AC, Brasil. [3]. Escola Superior de Ciências da Saúde, Universidade do Estado do Amazonas, Manaus, AM, Brasil.

[4]. Diretoria de Ensino e Pesquisa, Fundação de Medicina Tropical Dr. Heitor Vieira Dourado, Manaus, AM, Brasil.
\end{abstract}

\section{Dear Editor:}

Phyllomedusa bicolor is an Amazonian amphibian of the Phyllomedusidae Family, and is found in the forests of Brazil, the Guianas, Venezuela, Colombia, Peru, and Bolivia. It is one of the largest tree frogs of the Amazon. The males measure up to $11.8 \mathrm{~cm}$ from snout to vent ${ }^{1}$ (Figure 1A). Popularly known as "Kambô", "Kampô," or "Kampu," natives use the toxin secreted by the skin of this frog in traditional medicine ${ }^{1,2}$. The name Kambô is also used to describe the ritual of applying the poisonous secretions of the frog to the skin (Figure 1B). Natives also call the poisonous secretion "toad vaccine".

Indigenous people of Brazil and Peru remove the whitecolored secretion (Figure 1C) that the frog exudes when it is stimulated, and collect it on wooden spreaders for later use. This secretion is rich in bioactive peptides ${ }^{2}$ that the animal uses as a defense mechanism to kill or induce unpleasant experiences (e.g., discomfort, regurgitation) in predators that attempt to ingest this amphibian. Application of the "toad vaccine" is conducted by superficially burning the surface of the skin with a sharp object (or small piece of vine called "titica"), typically the arms of men or legs of women, and making several "points"2. The dried secretion from the spreader is then applied to each of the small burns/points ${ }^{2,3}$ (Figures 1B and 1D). The symptoms are almost immediate ${ }^{2}$, resulting in a great deal of discomfort (a strong burning sensation, nausea, stomach pain, and vomiting)

Corresponding author: Paulo Sérgio Bernarde.

e-mail: SnakeBernarde@hotmail.com

Orcid: 0000-0002-2191-7817

Received 27 October 2018

Accepted 18 December 2018

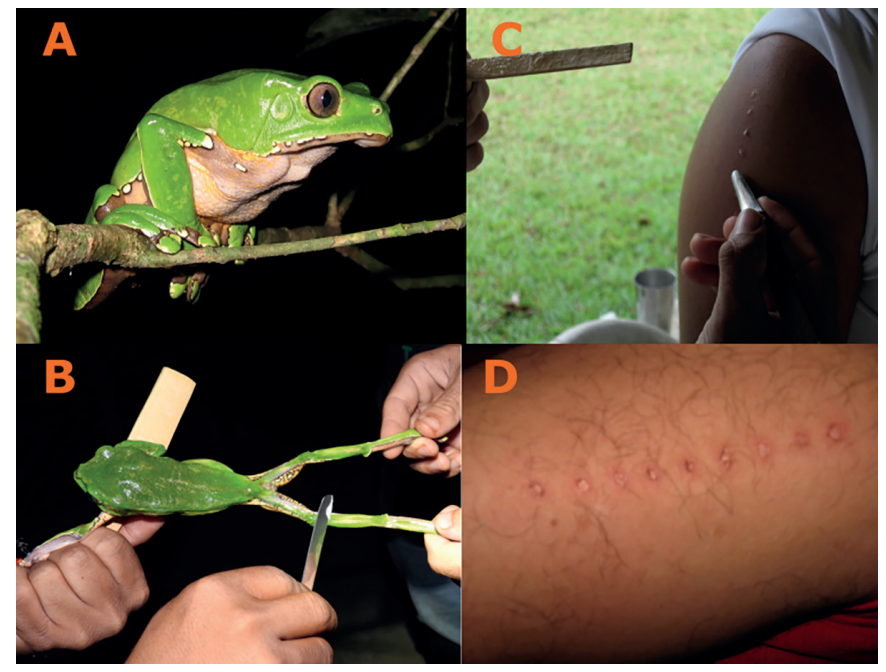

FIGURE 1: (A) Kambô frog (Phyllomedusa bicolor); (B) Removal of amphibian skin secretion P. bicolor, (C) Application of Kambô; (D) Marks on the shoulder after application of Kambô. Photos: Paulo Bernarde.

for approximately 15 minutes. However, relief can only be achieved by removing the poison from the skin by washing the affected area. Fasting the night before the application and drinking plenty of water is also recommended ${ }^{2}$.

For centuries indigenous people have used Kambô as a form of medicine to "strengthen the body's natural defenses," to ward off "panema" (bad luck), and in rituals to increase hunting success ${ }^{3}$. With the colonization of the Brazilian state of Acre, rubber tappers adopted this technique, and the ritual is now customary in several regions of Brazil, including in large urban centers ${ }^{3}$, and has reached North America and Europe ${ }^{2}$. It has been reported that peptides isolated from the skin secretions of the Phyllomedusa species exhibit antimicrobial properties 
(e.g., against Pseudomonas aeruginosas) and also inhibit protozoa (e.g., Trypanosoma cruzi) ${ }^{4}$ in vitro. This suggests a role for amphibians in the development of new anti-microbial drugs.

Recent reports have revealed the side-effect of $\operatorname{Kambo}^{5,6,7,8,9}$ treatment, including death ${ }^{10}$. Leban et al..$^{5}$ reported the case of a 44-year-old female in Slovenia who drank six liters of water after applying Kambô, and gradually developed nausea, vomiting, confusion, lethargy, muscle weakness and spasms, fits/convulsions, loss of consciousness, short-term memory, and developed syndrome of inappropriate antidiuretic hormone (SIADH) secretion. Pogorzelska and Lapiński ${ }^{6}$ treated a 34-year-old male patient in Poland with a chronic history of alcohol and marijuana use, who had signs of transient hepatitis, with Kambô to maintain sobriety. Kumachev et al. ${ }^{7}$ also reported the case of a 32-year-old female patient who was admitted to a hospital in Canada with prolonged nausea, frequent episodes of vomiting, and abdominal discomfort eight hours after Kambô treatment. Li et al. ${ }^{8}$ treated a 24-year-old female at a first-aid facility in the United States with symptoms of prolonged vomiting, facial flushing, facial swelling, altered mental status, and restlessness 22 hours after using Kambô. Roy et al. ${ }^{9}$ also reported the case of a 33-year-old woman in the United States who presented with potential psychosis (with characteristics of paranoia, anxiety, bizarre delusions, labile humor, and panic attacks) associated with Kambô use. The sudden death of a 42-year-old overweight man with signs of coronary disease associated with the use of Kambo was reported in Italy ${ }^{10}$. These authors suggested that the hypotensive effects of Kambô may have resulted in reduced myocardial perfusion and tachycardia, which led to sudden cardiac arrhythmia. In Pindamonhangaba, in the state of São Paulo (Brazil), the death of a 52-year-old man was reported shortly after the application of the Kambô by a practitioner who obtained the Kambô skin secretions from of the state of Acre ${ }^{11}$. All of these complications have been reported in regions far from where Kambô is traditionally used (Western Amazon), and applied by practitioners who may not have the same experience as those who traditionally perform the ritual, and thus poses an additional health risk.

In addition to its traditional use, Kambô has spread via urban expansion into alternative therapy clinics and Brazilian Ayahuasca religions (Santo Daime and União do Vegetal) with new practitioners, called holistic and medical therapists ${ }^{3}$. Natives are concerned that new practitioners may misapply Kambô or use the skin secretions of other species of amphibians ("Sapo-cururu" Rhinella marina), resulting in health complications or even death. Many people have reported the benefits of this therapy as if it were a "panacea" that is able to cure many diseases (low immunity, headache, gastritis, diabetes, blood pressure problems, cirrhosis, labyrinthitis, epilepsy, impotence, depression, cancer and AIDS $^{3}$ ). These reported benefits may increase the demand for alternative treatments like Kambo ; however, evidence of its efficacy is insufficient and studies of its side effects have not been conducted. The National Sanitary Surveillance Agency ${ }^{12}$ has ordered the suspension of all types of advertising for this alternative therapy, and revealed that there is no scientific evidence to guarantee the quality, safety, and efficacy of this treatment or its indication for any type of disease, imbalance, or treatment of any acute and chronic processes.
Due to the reports of complications and death, it is necessary to caution the public on the contraindications regarding the use of $K a m b \hat{o}^{2}$, such as severe cardiovascular conditions, hypotensive syndromes, and to limit water intake after the ritual, in order to reduce the risk of contracting SIADH syndrome. In addition, since Kambô is also traditionally used to induce abortions, pregnant women should not participate in this ritual ${ }^{2}$. Excessive applications (overdose), and treatment of children with a lower body mass, should be avoided as mass-to-dose ratio may be relatively higher during the treatment in these two groups of patients. The secretion of $P$. bicolor contains several different uncharacterized toxins ${ }^{6}$. Additional studies on the pharmacological potential of amphibians are necessary, and the risk of bio-piracy should be monitored. Trafficking of these animals and their secretions, and the possible impact on the P. bicolor population in their natural habitats, should be expensively studied.

Conflict of Interest: The authors declare that there are no conflicts of interest.

\section{REFERENCES}

1. Souza MB. Anfíbios - Reserva Extrativista do Alto Juruá e Parque Nacional da Serra do Divisor, Acre. Série Pesquisa e Monitoramento Participativo em Áreas de Conservação Gerenciadas por Populações Tradicionais. Vol 2. Campinas: Instituto de Filosofia e Ciências Humanas (IFCH) Unicamp; 2009. 77 p.

2. Hesselink, JMK. Kambô: A Shamanic Medicine - Personal Testimonies. JOJ Case Stud. 2018;8(3):555739.

3. Lima EC, Labate BC. "Remédio da Ciência" e "Remédio da Alma": Os usos da secreção do Kambô (Phyllomedusa bicolor) nas cidades. Campos. 2007;8(1):71-90.

4. Leite JRSA, Silva LP, Rodrigues MIS, Prates MV, Brand GD, Lacava BM, Azevedo RB, Boccad AL, Albuquerque S, Bloch Jr. C. Phylloseptins: A novel class of anti-bacterial and anti-protozoan peptides from the Phyllomedusa genus. Peptides. 2005;26(4):565-73.

5. Leban V, Kozelj G, Brvar M. The syndrome of inappropriate antidiuretic hormone secretion after giant leaf frog (Phyllomedusa bicolor) venom exposure. Toxicon. 2016;120:107-9.

6. Pogorzelska J, Lapinski TW. Toxic hepatitis caused by the excretions of the Phyllomedusa bicolor frog - a case report. Clin Exp Hepatol. 2017;3(1):33-4.

7. Kumachev A, Zipursky JS, Weinerman AS, Thompson M. Poisoning from the Kambô ritual. CJEM. 2018;2:1-3.

8. Li K, Horng H, Lynch K, Smollin CG. Prolonged toxicity from Kambo cleansing ritual. Clin Toxicol (Phila). 2018;2:1-2.

9. Roy R, Baranwal A, Espiridion ED. Can overuse of Kambô cause psychosis? Cureus. 2018;10(6):e2770.

10. Aquila I, Gratteri S, Sacco MA, Fineschi V, Magi S, Castaldo P, et al. The biological effects of Kambo: is there a relationship between its administration and sudden death? J Forensic Sci. 2017;63(3):965-8.

11. Menocchi, S. Investigada morte de homem que tomou 'vacina do sapo'. Estadão (São Paulo). 2008. [updated 2008; cited 2008 Apr 25] Available from: https://www.estadao.com.br/noticias/ geral, investigada-morte-de-homem-que-tomou-vacina-dosapo, 162933

12. ANVISA. Resolução-RE $N^{\circ} 8$, de 29 de Abril de 2004. Agência Nacional de Vigilância Sanitária. Diário Oficial da União, Brasília, DF, Seção 1 N 82, p. 94, 2004 Apr 30. 